\title{
Health Risk and the Demand for Red Meat: Evidence from Futures Markets
}

\author{
Rodney G. Robenstein; Walter N. Thurman \\ Review of Agricultural Economics, Vol. 18, No. 4. (Oct., 1996), pp. 629-641.
}

Stable URL:

http://links.jstor.org/sici?sici=1058-7195\%28199610\%2918\%3A4\%3C629\%3AHRATDF\%3E2.0.CO\%3B2-7

Review of Agricultural Economics is currently published by American Agricultural Economics Association.

Your use of the JSTOR archive indicates your acceptance of JSTOR's Terms and Conditions of Use, available at

http://www.jstor.org/about/terms.html. JSTOR's Terms and Conditions of Use provides, in part, that unless you have obtained prior permission, you may not download an entire issue of a journal or multiple copies of articles, and you may use content in the JSTOR archive only for your personal, non-commercial use.

Please contact the publisher regarding any further use of this work. Publisher contact information may be obtained at http://www.jstor.org/journals/aaea.html.

Each copy of any part of a JSTOR transmission must contain the same copyright notice that appears on the screen or printed page of such transmission.

The JSTOR Archive is a trusted digital repository providing for long-term preservation and access to leading academic journals and scholarly literature from around the world. The Archive is supported by libraries, scholarly societies, publishers, and foundations. It is an initiative of JSTOR, a not-for-profit organization with a mission to help the scholarly community take advantage of advances in technology. For more information regarding JSTOR, please contact support@jstor.org. 


\title{
HEALTH RISK AND THE DEMAND FOR RED MEAT: EVIDENCE FROM FUTURES MARKETS
}

\author{
Rodney G. Robenstein and Walter N. Thurman
}

The literature on demand shifts for meat is extensive. Since 1977, a large number of studies have documented instabilities in aggregate meat demand equations estimated from time series data. (See Braschler; Chavas; Choi and Sosin; Dahlgran; Moschini; Moschini and Meilke [1984, 1989]; Nyankori and Miller; and Thurman.) The modal conclusion from these studies is that per-capita demands for red meats, beef, and pork have shifted inwards over time and that per-capita demands for poultry and fish have shifted out. In studies attempting to pinpoint the timing of shifts, the shifts seem to have occurred, or to have begun, in the mid-tolate 1970s.

These studies are not without their critics. Chalfant and Alston found fault with the parametric conclusions of the structural shift literature; they demonstrated that neither American nor Australian aggregate meat consumption data violate the weak axiom of revealed preference. Both Wohlgenant and, later, Alston and Chalfant argued that perceived structural instability may be due to the use of inappropriate empirical functional forms.

Almost no structural shift studies have analyzed causes of the shifts. ${ }^{1}$ However, most authors are willing to attribute the shifts to changes over time in the way that consumers view the health implications of eating red meat.

Robenstein is a farm business consultant with the Illinois Farm Business Farm Management Association. Thurman is a Professor of Agricultural and Resource Economics and Professor of Economics at North Carolina State University. The authors would like to thank Charles R. Knoeber and participants in the Agricultural Economics Workshop at North Carolina State University for helpful comments.

'Two useful exceptions are articles by Brown and Schrader and by Capps and Schmitz. Brown and Schrader developed an index of the frequency of occurrence of cholesterol discussion in professional medical journals and, in a time-series demand model, found that the demand for eggs was negatively related to the index. This
This interpretation is at least plausible: medical science has accumulated evidence that diets high in cholesterol and fat, both found in red meat, increase the risk of heart disease. However, the timing of the public's cholesterol concern is not obviously the same as the timing of the shifts found in empirical meat demand studies. While most demand studies find shifts in the mid-1970s, Shekelle and Liu reported that, as late as 1978 , only 13 percent of a sample of Chicago consumers were aware that too much cholesterol or fat in the diet might increase the risk of heart attacks. Evidence presented here shows that firm scientific conclusions as to the link between heart disease and cholesterol or fat were not available until the early 1980 s.

Annual time series data reveals only so much about consumer response to health information. This study explores an alternative, and potentially rich, source of information on consumer meat demands: red meat futures markets. Contracts for live and feeder cattle and for live hogs and pork bellies afford the opportunity and incentive for traders to register their beliefs about consumer demand. Daily futures market data are analyzed to answer the question: do traders, whose profits depend upon accurately forecasting meat demand, revise their demand forecasts when significant information is released on the negative health implications of eating red meat? This research finds that they do not.

conclusion was reached despite the estimation of an autonomous and negative egg demand trend. Capps and Schmitz used the same cholesterol information index in a time series analysis of meat demand. They found that the index was correlated with a negative trend in meat demand as well. 


\section{Announcement Effects in Red Meat Futures Markets}

A simple story motivates our study and connects consumers' beliefs to observable data: the demand for a food product depends, in part, upon its perceived health benefits. The health consequences of eating red meat have been of concern for the last 20 years and, to the extent that beliefs concerning those consequences have changed, one would expect demand shifts to have reflected those changes. Press reports about health consequences of red meat refer to scientific studies. Medical researchers are continually engaged in projects designed to establish causes of heart disease and the link to eating red meat. Consumers learn of scientific results in this area in at least two ways. They learn about the results of research by reading popular media reports on research projects. In addition, they learn through the advice of their doctors. Doctors may change their own beliefs about the red meat-heart disease connection by reading medical journals but they, too, may learn from the popular press.

Whenever there is a release of new information from a professionally credible source, it will have some impact on the beliefs of consumers and health care professionals. ${ }^{2}$ If consumers' beliefs are affected by the new information then their consumption patterns will be affected as well. If new information serves to strengthen consumers' belief in the causal relation between red meat consumption and heart disease, then the demand for red meats will shift inward. Such a shift in consumer demand would also be reflected in an inward shift in the derived, farmlevel demand for red meats. To the extent that supply curves for red meats are upward sloping, there should be near-term (if not long-term) reductions in prices. The hypothesized release of information that shifts back demand for red meat over a future period also implies a current lowering of red meat futures prices.

The methodology consists of three parts. First, credible new publicly-released information and the dates near which it became public are identified. Next, a relevant portfolio of futures

\footnotetext{
${ }^{2}$ Consumers may respond to information from noncredible sources as well.
}

prices that should be affected by red meat health-related information is identified. Finally, in a series of event study regressions, effects of the information releases are analyzed. These three components are discussed in turn.

\section{Health-related Research Announcements}

The Wall Street Journal is the source of cholesterol announcement information. This daily national publication pervades U.S. business and, because of its extensive coverage of futures markets, is likely to be read by futures traders. ${ }^{3}$ Relevant articles were located using The Wall Street Journal Index from 1971 to 1987 and the National Newspaper Index from 1988 to 1990. In searching for public announcement dates, key words such as "cholesterol," "health," "beef," "pork," "cattle," and "hogs" were used.

The article titles and summaries identified by the indexes were studied to identify those that discuss dietary cholesterol, blood serum cholesterol, or heart disease, in connection with red meat consumption. Relevant articles found prior to 1983 were sparse and less newsworthy than those after 1983. In fact, no articles were found for the years 1973, 1974, 1975, 1977, 1979, and 1981.

After culling irrelevant articles, 52 articles remained. Each article was categorized either as strengthening the links connecting red meat, dietary cholesterol, blood serum cholesterol, and heart disease or weakening one or more of those links. Thirty-three articles strengthen the red meat and coronary disease link and 19 weaken the link, covering the period 1971 through 1990.

A further classification identified each article as strong, moderate, or weak. Four characteristics were used to rank the articles. The four criteria for "strong" articles were that they: (1) contained actual news; (2) came from a reliable source; 3 ) received both a prominent size and location in the paper; and (4) took a firm stand, providing either positive or negative

${ }^{3}$ While The Wall Street Journal is certainly not the only media outlet to which consumers pay attention, it provides us with a consistent daily observation on announcements which is indexed. One could expand the analysis in the current article by including announcements from other media. 
information tied directly to one of the cholesterol links in question, especially dietary recommendations referring to red meat. "Moderate" articles contain information from respectable sources, but failed to maintain one of the other three ranking characteristics. Examples of "moderate" articles included editorials (not actual news), articles of only one or two paragraphs and not readily visible (possibly overlooked because of size and location), and articles which may mention dietary cholesterol and red meats, but concentrate more on drug use to lower cholesterol (leaving the significance of dietary cholesterol in question). "Weak" articles contained at least one of the four ranking characteristics, but tended to be less newsworthy, such as from sources with possible vested interests, and were written without a firm positive or negative stand toward the cholesterol links.

Of the 52 articles, nine "strong" articles were found, each positively supporting the cholesterol links, 14 "moderate" articles with nine positive and five negative links, and 30 "weak" articles with 16 positive and 14 negative links. Since all the "strong" articles and most of the "moderate" and "weak" articles occurred after 1982, only those articles between 1983 and 1990 were considered. Among these 36 articles were nine "strong" articles which positively supported red meat-heart disease links, eight of the 10 "moderate" articles were positive, and the nine of the 17 "weak" were positive. Because none of the "strong" and only two of the "moderate" articles took a negative stand toward the cholesterol links, negative articles were not used. The final sample comprised 26 articles supporting the link between either red meat consumption and blood cholesterol, blood cholesterol and heart disease, or red meat consumption and heart disease directly. Because the categorization of articles is somewhat subjective, the larger sample of 52 articles is summarized in the Appendix.

\section{Portfolios of Red Meat Futures Contracts and a Market Index}

Daily futures price data were collected for red meats traded on the Chicago Mercantile Exchange. The data consisted of daily closes from January 1983 through December 1990 for the live cattle (LC), feeder cattle (FC), pork bellies (PB), and live hogs (LH) contracts. To allow for later testing of long-term versus shortterm reactions in the market, prices from both the nearby contract and from the contract closest to maturing six months from the current date were collected. For example, in January, the nearby month for live hogs is February and the six-month contract is July.

To keep a continuous daily data series, the price from the nearby contract month is rolled over to the next trading contract month as the nearby contract expires. Since the nearby contract month becomes more noisy as it converges to the cash price in the month of expiration, the nearby contract month is rolled over on the first notice day. First notice occurs on the last trading day of the month before the expiration month for $\mathrm{FC}, \mathrm{PB}$, and $\mathrm{LH}$ and on the second to last trading day of the previous month for LC. For example, the June 1992 contract for LH would roll over Friday, May 29 and the June 1992 contract for LC on Thursday, May 28 . The six-month contract simply rolls over on the last trading day when the next trading contract becomes a closer approximation to six months from the current date. For example, on January 31, 1992 the July 1992 six-month contract for LC rolls over to the August 1992 contract. $^{4}$

Possible differences in short-run and longrun effects are accounted for with different versions of the red meat index. One version includes all four red meat contracts in both the nearby and six-month contracts. Another includes all four red meat contracts, but only in the nearby contracts. A third version includes the four red meat contracts, but only in the sixmonth contracts. If an announcement effect has both current and long-term effects, reactions should be detected in all four versions of the index. Otherwise, the longer-term six-month index should pick up announcement reactions that the nearby index does not, or vice versa. A fourth version of the red meat index includes both live cattle and feeder cattle in the nearby and six-month contracts but excludes the pork

${ }^{4}$ When measuring price changes, it is inappropriate to include roll-over dates, so they are dropped from the sample. 
contracts. Because beef consumption falls more dramatically in the 1980 s than pork consumption, this portfolio is used to study specific effects that announcements may have on beef demand.

\section{Event Study Regressions}

The methodology in this study was first applied by Fama et al. (FFJR). FFJR maintained the following market model:

$$
R_{i t}=\alpha_{i}+\beta_{i} M_{t}+e_{i t}
$$

where $R_{i t} \equiv$ rate of return on security $i$ at time $t$, $M_{t}=$ rate of return on the market index at time $t$, and $e_{i t}=$ random error for security $i$ at time $t$.

In this study, the Commodity Research Beureau (CRB) index serves as the market index. ${ }^{5}$ The role of the individual security is played by a portfolio of red meat futures contracts. The market model is adapted to control for uninteresting market-wide influences on red meat futures prices. The sensitivity of the return of security (futures contract) i to the return on the market index reflects co-movements among the commodities. Correlated movements among the commodities may indicate normal adjustments to macroeconomic influences such as interest rates, inflation, strength of the U.S. dollar, exports, and supply shocks. Conditioning on the CRB index increases the power of tests by holding constant futures price variation clearly unrelated to health announcements.

The rate of return on the red meat index is constructed such that an equal dollar amount is invested in each of the four red meat futures contracts: live cattle, feeder cattle, pork bellies, and live hogs. The portfolio is rebalanced daily. The return on this portfolio is calculated as follows. First, a daily return on a particular contract is defined as:

${ }^{5}$ The index "is an unweighted geometric mean of the individual price relatives of 27 (changed to 21 after 1986) commodity futures prices. ... The current price value in the index for each commodity is found by averaging all futures contracts up to, but not including, those that mature twelve months in advance of the present date" (Commodity research Bureau, 1984, p. 38). The ratio of current prices to the 1967 annual average price $(1967=100)$ of each commodity completes the CRB calculation. See the Appendix for a list of contracts included in the CRB index.

$$
r_{i t}=\ln p_{i t}-\ln p_{i t-1}
$$

where $r_{i t} \equiv$ rate of return on the $i^{\text {th }}$ contract on day $t, \ln \mathrm{p}_{\mathrm{it}} \equiv$ natural $\log$ of the price of the $\mathrm{i}^{\text {th }}$ contract on day $t$, and $\ln \mathrm{p}_{\mathrm{it}-\mathrm{I}} \equiv$ natural $\log$ of the price of the $i^{\text {th }}$ contract on day $t-1$. The rate of return on the red meat index is then calculated as:

$$
R_{t}=(1 / k) \sum_{i=1}^{k} r_{i t},
$$

where $\mathrm{k}$ is the number of contracts included in the red meat index.

To test effects of announcements on red meat futures, a regression model based on the structure proposed by FFJR is formed which includes dummy variables to indicate announcement dates and the 20 -day periods before and after:

$$
\begin{aligned}
\mathrm{R}_{\mathrm{t}} & =\alpha+\beta_{1} \mathrm{M}_{\mathrm{t}}+\beta_{2} \mathrm{AD}_{\mathrm{t}} \\
& +\sum_{\mathrm{i}=1}^{20} \gamma_{\mathrm{i}} \mathrm{BEF}_{\mathrm{it}}+\sum_{\mathrm{i}=1}^{20} \theta_{\mathrm{i}} \mathrm{AFT}_{\mathrm{it}}+\mathrm{u}_{\mathrm{t}}
\end{aligned}
$$

where $A D_{t}$ equals 1 on the 26 announcement dates; $\mathrm{BEF}_{\mathrm{it}}$ equals 1 on the $\mathrm{i}^{\text {th }}$ day before the announcement; and $\mathrm{AFT}_{\text {it }}$ equals 1 on the $\mathrm{i}^{\text {th }}$ day after the announcement. Rates of return computed from the red meat and CRB indices are used for $R_{t}$ and $M_{t}$.

If the announcement date, when $\mathrm{AD}_{\mathrm{t}}$ equals 1 , was the only date on which an effect occurred, then $\beta_{2}$ would be expected to be negative and all the $\gamma_{i}$ 's and $\theta_{i}$ 's to equal zero. However, information may be leaked to the market before the announcement date or markets may not digest the announcement instantly. For these reasons, a 20-day window on either side of the announcement is introduced. The sum of $\beta_{2}$, the $\gamma_{i}^{\prime}$ 's, and the $\theta_{i}$ 's is the regression estimate of the cumulative impact on returns from a single announcement.

To test announcement leaks or delays measured in months rather than days, a monthly futures returns model also is analyzed. The monthly returns model estimated is:

$$
\begin{aligned}
\mathrm{R}_{\mathrm{t}} & =\alpha+\beta_{1} \mathrm{M}_{\mathrm{t}}+\beta_{2} \mathrm{AM}_{\mathrm{t}} \\
& +\gamma \mathrm{BEF}_{\mathrm{t}}+\theta \mathrm{AFT}_{\mathrm{t}}+\mathrm{v}_{\mathrm{t}}
\end{aligned}
$$


where $R_{t}$ and $M_{t}$ now represent monthly rates of return on the appropriate indexes; $\mathrm{AM}_{\mathrm{t}}$ refers to an announcement month dummy variable; and $\mathrm{BEF}_{\mathrm{t}}$ and $\mathrm{AFT}$, signal months that are one month before and after months in which announcements are made. The daily market returns model is estimated first. Without dummy variables representing announcement effects, the estimate of the market returns model from January 1983 to December 1990 is:

$$
\begin{aligned}
R_{t}= & 0.0057+0.5199 M_{t}+u_{t}, \\
& (0.0207) \quad(0.0334)
\end{aligned}
$$

with an adjusted $\mathrm{R}^{2}$ of 0.1151 , a Durbin-Watson Statistic of 2.016 , and 1,858 observations. The standard errors for the regression parameters are shown in parentheses. The red meat index, $R_{t}$, used as the dependent variable includes all eight red meat contracts, live cattle, feeder cattle, pork bellies, and live hogs in both the nearby and six-month contracts. The parameter estimate for the CRB index is significantly different from zero. It can partially be explained by the fact that three of the red meat contracts are included in the index. However, it primarily reflects the reaction of red meats to other related commodities included in the index, especially grains. Significance of the CRB index persists throughout all of the market returns testing.

The event study regressions, estimates of equation (4), are reported in Table 1 for the four versions of the red meat futures index. Table 2 defines four indices used to measure red meat price changes. Initial regressions that used all 26 announcements (strong, moderate, and weak) showed no significance, individually or joint, of the announcement day dummies. Therefore, only regressions using "strong" announcement dates are presented in Table 1.

As expected, the CRB market index parameter estimate is highly significant in the four regressions with different measures of red meat price changes. The four measures are: $\mathrm{RRM}_{\mathrm{t}}$ (the change in nearby and six-month beef and pork contracts); $\mathrm{RNB}_{\mathrm{t}}$ (the change in nearby beef and pork contracts); $\mathrm{R}_{6} \mathrm{M}_{\mathrm{t}}$ (the change in six-month beef and pork contracts); and RCAT (the change in nearby and six-month beef contracts). A 1 percent change in the market index is associated with about a 0.5 percent change in the red meat index when $R R M_{t}$, $\mathrm{RNB}_{t}$, and $\mathrm{R} 6 \mathrm{M}_{\mathrm{t}}$ are used and a 0.25 percent increase if RCAT $_{t}$ is used. Since the CRB index is less representative of cattle contracts alone, its parameter estimate is lower when $\operatorname{RCAT}_{t}$ is used.

The estimated announcement date dummy parameter (not shown) has an insignificant $t$ statistic, so the collective effect of the days on and around the announcement date are examined for evidence of abnormal market behavior. Testing for a collective effect using the t-statistics of the individual dummy coefficients (which represent days on and around the announcement) is unreliable. In fact, under the null hypothesis, one would expect to find one or two of the 41 dummy coefficient estimates significant when such a test is performed at the 5 percent level. ${ }^{6}$ Therefore, an F-test is performed to determine if the dummy variables are jointly significant. At the 5 percent level, none of the red meat index models show a significant joint F-statistic for the nine strongest announcement dates. $^{7}$

An F-test to determine if the sum of the dummy estimates is significantly different from zero is also performed. For the nine strongest announcement dates, none of the models exhibit a sum of coefficients that is significantly different from zero at the 5 percent level.

Beyond testing for statistical significance, economic significance of the results is considered. A 90 percent confidence interval for the sum of the dummy coefficients is computed for the following reasons. If zero is contained

${ }^{6}$ Dummy variables include the announcement date, 20 days preceding, and 20 days following. The inclusion of dummies for several announcement dates ensures that each dummy variable lands on a non-roll-over date, validating all 41 dummy variables. However, when testing a single announcement date, three contract roll-over dates will occur within this window, leaving three dummy variables invalid.

${ }^{7}$ Results reported in Table 1 measure red meat return with the four portfolios described in Table 2. The four portfolios represent different combinations of the eight pork and beef contracts. Numerous other portfolios could be constructed from other subsets of the eight contracts. We investigated the same empirical relationships using other portfolios, including portfolios consisting of just one of the eight futures contracts. The key result described in the text, the non-significance of the cumulative announcement effect, is robust to choice of portfolio. 
634 REVIEW OF AGRICULTURAL ECONOMICS, Vol. 18, No. 4, October 1996

Table 1. Daily Market Returns Model Results, Nine Strong Announcement Dates

\begin{tabular}{|c|c|c|c|c|}
\hline & $\mathrm{RRM}_{\mathrm{t}}$ & $\mathrm{RNB}_{1}$ & $\mathrm{R} \mathrm{M}_{\mathrm{t}}$ & $\mathrm{RCAT}_{1}$ \\
\hline Intercept & $\begin{array}{c}0.0047 \\
(0.0225)^{\mathrm{a}}\end{array}$ & $\begin{array}{c}0.0032 \\
(0.0246)\end{array}$ & $\begin{array}{c}0.0062 \\
(0.0215)\end{array}$ & $\begin{array}{c}0.0272 \\
(0.0189)\end{array}$ \\
\hline $\mathrm{M}_{\mathrm{t}}$ & $\begin{array}{r}0.5130^{b} \\
(0.0336)\end{array}$ & $\begin{array}{r}0.5050^{\mathrm{a}} \\
(0.0367)\end{array}$ & $\begin{array}{c}0.5219^{\mathrm{a}} \\
(0.0321)\end{array}$ & $\begin{array}{c}0.2407^{\mathrm{a}} \\
(0.0282)\end{array}$ \\
\hline Sum of Dummy Coefficients & 0.1505 & 0.3718 & -0.0708 & -0.3100 \\
\hline F-stat (joint) & $\begin{array}{c}0.9220 \\
(0.6131)\end{array}$ & $\begin{array}{c}1.0139 \\
(0.4470)\end{array}$ & $\begin{array}{c}0.8426 \\
(0.7468)\end{array}$ & $\begin{array}{c}0.7952 \\
(0.8171)\end{array}$ \\
\hline F-stat (sum) & $\begin{array}{c}0.0058 \\
(0.9394)\end{array}$ & $\begin{array}{c}0.0125 \\
(0.9109)\end{array}$ & $\begin{array}{c}0.0017 \\
(0.9675)\end{array}$ & $\begin{array}{c}0.0318 \\
(0.8565)\end{array}$ \\
\hline 90 percent C.I. (sum) & $\begin{array}{r}(-3.09 \\
3.39)\end{array}$ & $\begin{array}{r}(-5.08 \\
5.83)\end{array}$ & $\begin{array}{r}(-2.89 \\
2.75)\end{array}$ & $\begin{array}{r}(-3.16 \\
2.54)\end{array}$ \\
\hline Average Return ${ }^{c}$ & 4.9187 & 5.7158 & 4.3322 & 3.6129 \\
\hline Adjusted $\mathrm{R}^{2}$ & 0.1136 & 0.0957 & 0.1248 & 0.0342 \\
\hline Mean Squared Error & 0.800 & 0.9529 & 0.7294 & 0.5614 \\
\hline Durbin-Watson & 2.012 & 1.998 & 1.997 & 2.009 \\
\hline $\mathrm{n}$ & 1,858 & 1,858 & 1,858 & 1,858 \\
\hline
\end{tabular}

Dependent variables are measured in daily percentage changes, not annualized.

${ }^{a}$ Numbers in parentheses represent standard errors for coefficients and p-values for F-statistics.

${ }^{b}$ Indicates coefficient significantly different from zero at the 5 percent level.

${ }^{\mathrm{c}}$ The average of absolute percentage changes of the red meat index over all 41 -day intervals in the sample.

Table 2. Futures Contracts Included in the Four Red Meat Futures Indices

\begin{tabular}{lcccc}
\hline Contract & $\mathrm{RRM}_{1}$ & $\mathrm{RNB}_{1}$ & ${\mathrm{R} 6 \mathrm{M}_{1}}$ & $\mathrm{RCAT}_{1}$ \\
\hline LC-nearby & $\checkmark$ & $\checkmark$ & & $\checkmark$ \\
LC-sixth month & $\checkmark$ & & $\checkmark$ & $\checkmark$ \\
FC-nearby & $\checkmark$ & $\checkmark$ & & $\checkmark$ \\
FC-sixth month & $\checkmark$ & & $\checkmark$ & \\
PB-nearby & $\checkmark$ & $\checkmark$ & & $\checkmark$ \\
PB-sixth month & $\checkmark$ & & $\checkmark$ & \\
LH-nearby & $\checkmark$ & $\checkmark$ & & \\
LH-sixth month & $\checkmark$ & & $\checkmark$ & \\
\hline LC = live cattle, & & & \\
FC = feeder cattle, & & & \\
PB = pork bellies, & & \\
LH = live hogs.
\end{tabular}


within the interval (as is found), an argument for abnormal returns around the announcement date is weak. This settles the issue of statistical significance. However, a failure to reject a null hypothesis can be interpreted in two ways. One could conclude either that there is no announcement effect or that the data are too weak to detect it. But, if the 90 percent confidence interval contains only returns that are deemed to be economically small then the regression estimates the announcement effect to be economically insignificant, and this is found.

The question arises: what is a reasonable measure of the economic significance of a daily return? Because the sum of the dummy variables in the event study regressions represents the cumulative effect, over 41 days, of a single announcement, it is compared to the unconditional average of the market's movements over all 41 -day periods. The 41-day average return is computed by summing the daily returns over a 41-day interval, taking its absolute value, and averaging all of the possible 41-day returns for the entire sample period. The resulting figure can be interpreted as the average amount by which the market goes up or down over a 41 day period.

All of the confidence intervals in Table 1 are zero, establishing the lack of statistical significance of the announcement effect. As to economic significance, the lower (negative) end of the confidence interval is compared with the average absolute 41-day return. For example, the 90 percent confidence interval for $R R M_{t}$ is bounded by -3.09 percent and 3.39 percent. Relative to the 41-day average movement of 4.92 percent, the confidence interval bounds support with 90 percent confidence that excess returns due to announcements are economically insignificant for the nine strongest announcement dates. The 41-day average movement is compared with the low, and negative, end of the confidence interval because of interest are negative effects of cholesterol announcements as demonstrated by negative returns in the red meat market.

The 41-day average movement in the red meat index is reported in Table 1 for each of the four index versions. For the nine announcements, each of the four models exhibits statistically and economically insignificant excess returns. Similar results hold for regressions that use all positively ranked announcement dates: strong, moderate, and weak. Further, each of the nine strong dates is analyzed in its own regression. All the announcement dates, except one, exhibit similar insignificant results. The one significant date is October 5, 1987 and its regressions are reported in Table 3. On that date, an article in The Wall Street Journal appeared on the first page of the second section, "Doctors' Orders: Cholesterol Study Calls for Broad Treatment Change." Included were recommendations by the National Heart, Lung, and Blood Institute that "doctors monitor every American adult's cholesterol level and prescribe specific diets...with detailed lists of unacceptable and acceptable foods, mostly recommending that patients avoid high-fat foods... and limit their intake of fatty beef and veal" (p.131). For this announcement date, the F-statistic for the sum of the dummy coefficients was significant at the 5 percent level.

Events surrounding the specific date were further investigated. Cattle prices dropped precipitously in October $1987 .^{8}$ According to reports in The Wall Street Journal, traders began worrying about falling cattle demand and excess fat cattle inventories as cattle futures began a two-week slump starting in the last week of September. The week of October 19 through 22 saw cattle futures drop by $\$ 4.50$ per hundredweight, making for "the worst week since spring 1986, when the U.S. announced plans to pay dairy operators to slaughter their herds" (Siconolfi, p. 40). On October 26, cattle and hog contracts fell by the permissible limit of $\$ 1.50$ per hundredweight and pork bellies by $\$ 2.00$ per hundredweight. Analysts blamed a bearish cattle-inventory report from the United States Department of Agriculture and stock market declines. Given the extraordinary cir cumstances in the cattle market during this period and that no Wall Street Journal commentary at the time attributed the meat futures drop to the October 5 health announcement, the abnormal returns were unlikely to have been caused by cholesterol announcement effects.

\footnotetext{
${ }^{8}$ Coincidentally or not, October 19,1987 was the date of the stock market crash.
} 
Table 3. Daily Market Returns Model Results, Individual Announcement Date, October 5, 1987

\begin{tabular}{|c|c|c|c|c|}
\hline & $\mathrm{RRM}_{\mathrm{t}}$ & $\mathrm{RNB}_{\mathrm{t}}$ & $\mathrm{R}^{2} \mathrm{M}_{\mathrm{t}}$ & $\mathrm{RCAT}_{\mathrm{t}}$ \\
\hline Intercept & $\begin{array}{c}0.0122 \\
(0.0209)^{a}\end{array}$ & $\begin{array}{c}0.0113 \\
(0.0229)\end{array}$ & $\begin{array}{c}0.0130 \\
(0.0199)\end{array}$ & $\begin{array}{c}0.0312 \\
(0.0173)\end{array}$ \\
\hline$M_{1}$ & $\begin{array}{r}0.5182^{b} \\
(0.0337)\end{array}$ & $\begin{array}{r}0.5107^{b} \\
(0.0369)\end{array}$ & $\begin{array}{r}0.5257^{b} \\
(0.0321)\end{array}$ & $\begin{array}{r}0.2367^{b} \\
(0.0280)\end{array}$ \\
\hline Sum of Dummy Coefficients & -11.998 & -11.538 & -12.458 & -9.8128 \\
\hline F-stat (joint) & $\begin{array}{c}1.2978 \\
(0.1065)\end{array}$ & $\begin{array}{c}1.1103 \\
(0.2971)\end{array}$ & $\begin{array}{c}1.4389 \\
(0.0411)\end{array}$ & $\begin{array}{c}2.0301 \\
(0.0002)\end{array}$ \\
\hline F-stat (sum) & $\begin{array}{c}4.6751 \\
(0.0307)\end{array}$ & $\begin{array}{c}3.6104 \\
(0.0576)\end{array}$ & $\begin{array}{c}5.5566 \\
(0.0185)\end{array}$ & $\begin{array}{c}4.5367 \\
(0.0333)\end{array}$ \\
\hline 90 percent C.I. (sum) & $\begin{array}{r}(-21.10 \\
-2.90)\end{array}$ & $\begin{array}{r}(-21.50 \\
-1.58)\end{array}$ & $\begin{array}{r}(-21.13 \\
-3.79)\end{array}$ & $\begin{array}{r}(-17.37 \\
-2.26)\end{array}$ \\
\hline Average Return ${ }^{c}$ & 4.9187 & 5.7158 & 4.3322 & 3.6120 \\
\hline Adjused $\mathrm{R}^{2}$ & 0.1205 & 0.0978 & 0.1360 & 0.0588 \\
\hline Mean Squared Error & 0.7938 & 0.9506 & 0.7200 & 0.5471 \\
\hline Durbin-Watson & 2.007 & 1.993 & 1.994 & 2.023 \\
\hline$\underline{n}$ & 1,858 & 1,858 & 1,858 & 1,858 \\
\hline
\end{tabular}

Dependent variables are measured in daily percentage changes, not annualized.

${ }^{a}$ Numbers in parentheses represent standard errors for coefficients and p-values for F-statistics.

${ }^{b}$ Indicates coefficient significantly different from zero at the 5 percent level.

${ }^{\text {c}}$ The average of absolute percentage changes of the red meat index over all 41 -day intervals in the sample.

The monthly market returns model is tested next. Without dummy variables representing the announcement month or the month before and after, the empirical estimate of the market model is:

$$
\begin{aligned}
R R M_{t}= & 0.0072+0.3501 M_{t}+v_{t}, \\
& (0.0211)(0.1393)
\end{aligned}
$$

with an adjusted $\mathrm{R}^{2}$ of 0.0530 , a Durbin-Watson Statistic of 1.8626 , and 96 observations.

The announcement effect regressions are repeated with the monthly average data, but again the null hypothesis of no announcement effect cannot be rejected. Further, the confidence intervals for the estimated effect are always small relative to actual average returns. For individual announcement date regressions, only the October 1987 announcement proves significant. Only the announcement month is significant, not the month before or the month after. This result strengthens the argument that both the monthly and daily tests for this period are affected by extraneous forces.

\section{Conclusions}

The most obvious times that public knowledge of the links between red meat consumption and heart disease could be said to have changed were identified. On those dates, reactions in futures markets, the most obvious place for immediate adjustments to occur, were examined. No evidence was found of any such adjustment. Further, failure to find evidence of a reaction is not due to weak data. Probable bounds on the size of a futures price reaction to health information were identified and were small in economically relevant terms.

The link between health perceptions and red meat demand has been discussed extensively and previous empirical work has shed useful, albeit indirect, light on the question. What seems clear is that structural change analysis of time series demand models has not settled the issue of whether or not red meat demands have shifted. The current article examines a different sort of information and expands the set of tested implications of a health-linked demand shift. 
A different interpretation of the results is that futures markets are not, in fact, likely places to look for evidence of shifts in demand. Futures prices are volatile and their movements reflect many short-term phenomena. One could argue that the changes in red meat demand are gradual and that they are unlikely to register in futures prices, even if they are cumulatively large.

There is a difference between taking a position in a live cattle contract for delivery two months hence and forecasting demand for beef one or two years hence. However, long-term demand shifts, whatever their cause, show up at some time in futures prices and traders who anticipate those shifts will profit. If identifiably important public releases of information have no discernible reaction in the futures market, then two conclusions are possible. Either reasonable forecasts of meat demand should be unchanged by scientific evidence on the health consequences of eating red meat or futures traders are ignoring this information. We do not believe futures traders consistently and persistently fail to react to important information. Rather, a lack of reaction from the futures market calls into question the link between the scientific pronouncements and consumer behavior.

[Received June 1994. Final version received July 1996.]

\section{References}

Alston, J.M. and J.A. Chalfant. "Can We Take the Con Out of Meat Demand Studies?" Western Journal of Agricultural Economics 16(1991):36-48.

Braschler, C. "The Changing Demand Structure for Pork and Beef in the 1970s: Implications for the 1980s." Southern Journal of Agricultural Economics 15(1983): 105-10.

Brown, J.B. and L.F. Schrader. "Cholesterol Information and Shell Egg Consumption." American Journal of Agricultural Economics 72(1990):548-55

Capps, Jr., O. and J.D. Schmitz. "A Recognition of Health and Nutrition Factors in Food Demand Analysis." Western Journal of Agricultural Economics 16(1991):21-35.
Chalfant, J.A. and J.M. Alston. "Accounting for Changes in Taste." Journal Political Economics 96(1988):391-410.

Chavas, J.P. "Structural Change in the Demand for Meat." American Journal of Agricultural Economics 65(1983):148-53.

Choi, S. and K. Sosin. "Testing for Structural Change: The Demand For Meat." American Journal of Agricultural Economics 72(1990):227-36.

Commodity Research Bureau, Inc. Commodity Year Book. Jersey City, NJ: Commodity Research Bureau, Inc., 1984

Dahlgran, R.A. "Complete Flexibility Systems and the Stationarity of U.S. Meat Demand." Western Journal of Agricultural Economics 12(1987):152-63.

Fama, E.F., L. Fisher, M.C. Jensen, and R. Roll, "The Adjustment of Stock Prices to New Information." International Economics Revue 10(1969):1-21.

Moschini, G. "Testing Preference Change in Consumer Demand: An Indirectly Separable Semiparametric Model." Journal of Business and Economic Statistics 9(1991):111-17.

Moschini, G. and K.D. Meilke. "Parameter Stability and the U.S. Demand for Beef." Western Journal of Agricultural Economics 9(1984):271-82.

and K.D. Meilke. "Modelling the Pattern of Structural Change in U.S. Meat Demand." American Journal of Agricultural Economics 71(1989):253-61.

National Newspaper Index. Foster City, CA: Information Access Company, 1988-1990.

Nyankori, Y.C.O. and G.H. Miller. "Some Evidence on Applications of Structural Change in Retail Demand for Meats.: Southern Journal of Agricultural Economics 14(1982):65-70.

Shekelle, R.B. and S. Liu. "Public Beliefs About Causes and Prevention of Heart Attacks." Journal American Medical Association 240(1978):756-58.

Siconolfi, M. "Commodities." The Wall Street Journal. (1987, October 23). p. 40.

Thurman, W.N. "The Poultry Market: Demand Stability and Industry Structure." American Journal of Agricultural Economics 69(1987):30-37.

Wall Street Journal Index, The. Ann Arbor, MI: University Microfilms International, 1971-87.

Wohlgenant, M.K. "Estimating Cross Elasticities of Demand for Beef." Western Journal of Agricultural Economics 10(1985):322-29. 
Appendix Table 1. Selected Wall Street Journal Article Summaries

\begin{tabular}{ccl}
\hline Ranking & Date & Summary \\
\hline +W & $1 / 6$ & $\begin{array}{l}\text { Our Daily Bread: Nutrition experts say Americans are eating themselves to death; variety of ills } \\
\text { are linked to bad diets, but doctors can not agree what's right. }\end{array}$ \\
$+\mathrm{W}$ & $11 / 15$ & $\begin{array}{l}\text { Diet and heart test of thousands of men evidently shelved; U.S.-backed program to study effects } \\
\text { of high-fat intake may be sliced to cut costs. }\end{array}$ \\
$+\mathrm{W}$ & $12 / 10$ & $\begin{array}{l}\text { Program to combat heart disease urged by National Institute of Health advisory committee, citing } \\
\text { arteriosclerosis epidemic. }\end{array}$
\end{tabular}

1972

$-\mathrm{W} \quad 5 / 15$

Baxter Laboratories, Inc.'s Choloxin dropped from study after deaths increase; link to heart-disease fatalities feared in nationwide testing of cholesterol-lowering drugs.

$+\mathrm{W} \quad 11 / 17$

Dow Chemical Company drug to lower cholesterol is termed "promising"; American Heart Association is told tests show it aids persons with the coronary risk factor.

1976

$\begin{array}{ll}\text {-W } & 7 / 19 \\ +\mathrm{M} & 9 / 14 \\ \text {-W } & 11 / 17\end{array}$

Considerable confusion developing among doctors as well as patients over the most desirable level of cholesterol in the blood, head of an expert panel on heart disease said.

Theory traces link between cholesterol and heart disease; researchers say high level curbs normal healing of injuries to arteries.

Diet high in fiber found not to lower levels of cholesterol; study by University of Oregon Sciences Center finds such plans don't offer any aid to avert heart disease.

\section{8}

New confusion was thrown into the research linking high cholesterol levels in the blood in heart attacks.

\section{0}

$-\mathrm{M} \quad 6 / 5$

Mrs. Flynn's 600 help take the fat out of diet research; an 11-year study at the University of Missouri campus is involved in cholesterol debate; colleagues watch 'bods.'

$-\mathrm{W} \quad 6 / 13$

Cholesterol controversy moves to Capitol Hill; A skeptical House subcommittee summons members of the Food and Nutrition Board to explain their report that healthy Americans need not cut intake of fat and cholesterol to avoid heart attacks.

Science Academy's Cholesterol Report Spatters in Capitol: Editorial page article concerning the National Academy of Science's report on cholesterol, which began the cholesterol controversy: The Academy is going to survive the report; yet the Academy, like other scientific organizations that depend for their usefulness on the existence of at least a small amount of self-restraint in the political environment, may eventually not be so safe.

Cholesterol contretemps fail to change practicing doctors' views: An informal survey of physicians reveals that most continue to urge patients to watch what they eat despite a National Academy of Sciences' panel report that healthy Americans need not be concerned about reducing fat and cholesterol consumption.

$-\mathrm{W} \quad 10 / 14$

Hints are starting to pop up that altering the body's cholesterol makeup to prevent a heart attack may increase the risk of cancer.

\section{2}

$+\mathrm{W} \quad 7 / 7$

A nutrition group, Center for Science in the Public Interest, released copies of a "suppressed" Agriculture Department document that advocates limiting the consumption of fats and cholesterol to reduce the risk of heart attack.

Food Fare: An editorial "Aside" highlighting the latest data showing that Americans are eating less beef and more chicken.

‡Summaries as described in The Wall Street Journal Index and National Newspaper Index.

$\$(+)$ and $(-)$ indicate whether an article supports or weakens the link between red meat consumption and coronary disease; W, $\mathrm{M}$, and $\mathrm{S}$ indicate weak, moderate, or strong articles as described in the text. 


\section{Appendix Table 1, Cont'd. Selected Wall Street Journal Article Summaries}

\begin{tabular}{|c|c|}
\hline Rankings Date & Summary \\
\hline & 1983 \\
\hline$+W \quad 10 / 18$ & $\begin{array}{l}\text { Cattle raising takes unprecedented turns, largely because of changes in consumer demand for beef } \\
\text { products. }\end{array}$ \\
\hline
\end{tabular}

1984

$+S \quad 1 / 10 \quad$ Scientists are establishing final links in the chain of evidence linking cholesterol to heart attacks and coronary heart disease; have discovered a host of genetic defects that impair body's ability to handle excessive cholesterol in the blood stream.

$+\mathrm{S} \quad$ A new government study indicates that a cholesterol-lowering diet combined with drug treatment can cut risk of heart disease as much as 50 percent in persons with high blood-cholesterol levels.

+ W 2/16 Family restaurants play down red meat and offer more chicken and fish in response to concern over the health effects of red meat.

$+\mathrm{S} \quad$ 3/15 Cholesterol levels in American children are too high and should be lowered to reduce the risk of a heart attack later in life.

$+\mathrm{S} \quad 5 / 16 \quad$ At least 5 percent of American adults should be treated for excessive cholesterol in the bloodstream, the American Heart Assoc. says; at least half of all American adults have too much cholesterol in the blood, increasing the chances of coronary heart disease.

$+\mathrm{M} \quad 7 / 12$

Cholestyramine: The FDA granted Mead Johnson Laboratories permission to flatly state in labels that its Questran-brand Cholestyramine medicine lowers the risk of coronary heart disease and heart attacks in patients with excessive cholesterol, giving the firm an advantage over its marketing rivals.

The National Institutes of Health approved recent conclusions that high blood cholesterol causes heart attacks and that Americans should eat less fatty foods that raise cholesterol levels.

1985

Cholesterol levels called "normal" on lab reports are often too high, say University of Nebraska heart researchers; many labs call readings of as much as 270 normal, although 125 to 200 is the ideal range for preventing heart attacks.

\section{6}

New findings show that a diet rich in monounsaturated fat is more effective in maintaining a proper cholesterol balance to prevent heart disease; finding is contrary to popular American belief of reducing the amount of fat consumed to 30 percent of diet.

\section{7}

$-\mathrm{W} \quad 2 / 3$

Risk Factor: Inaccuracy in testing cholesterol hampers war on heart disease; some diagnoses are skewed by glitches such as use of ill-calibrated lab gear; missing the mark by 100 percent.

Doctors will draw on new insight from thousands of experiments - and a variety of new drugs - to decide how and when to treat patients with a high cholesterol count.

Doctors are ordering many patients on low-fat diets or even drugs, to fight cholesterol levels previously classed as normal; the new attack on cholesterol is aimed at lowering the toll of heart disease; includes chart.

-M 5/11 Proctor \& Gamble's olestra, a calorie-and-cholesterol-free fat substitute, creates promise of a dietary breakthrough; it also eliminates some cholesterol already in the body.

$-\mathrm{W} \quad 6 / 8$

A panel of health experts under the direction of the National Heart, Lung, and Blood Institute called inaccurate cholesterol measurements a "major problem" that must be overcome if heart disease is to be brought under control.

'Summaries as described in The Wall Street Journal Index and National Newspaper Index.

$\$(+)$ and $(-)$ indicate whether an article supports or weakens the link between red meat consumption and coronary disease; W, $\mathrm{M}$, and $\mathrm{S}$ indicate weak, moderate, or strong articles as described in the text. 


\section{Appendix Table 1, Cont'd. Selected Wall Street Journal Article Summaries}

\begin{tabular}{|c|c|c|}
\hline \multicolumn{2}{|c|}{ Ranking $^{\S}$ Date } & Summary \\
\hline \multicolumn{3}{|r|}{1987 Cont'd. } \\
\hline$+\mathrm{M}$ & $6 / 19$ & $\begin{array}{l}\text { An experiment in heart patients who have had bypass surgery show that lowering blood cholesterol levels } \\
\text { slows or even reverses the clogging of coronary arteries. }\end{array}$ \\
\hline$+\mathrm{S}$ & $10 / 5$ & $\begin{array}{l}\text { Doctors' Orders: Cholesterol study, by the National Heart, Lung, and Blood Institute's National } \\
\text { Cholesterol Education Program, calls for sweeping changes in treating heart disease; report recommends } \\
\text { that doctors monitor American adult's cholesterol level and prescribe specific diets, or drugs, for those } \\
\text { at risk; recommendations are likely to raise health-care costs. }\end{array}$ \\
\hline$-\mathrm{M}$ & $10 / 23$ & $\begin{array}{l}\text { Take Cholesterol Plan With a Grain of Salt: Editorial-page article by Elizabeth Whelan criticizes the } \\
\text { National Heart, Lung, and Blood Institute's recommendation that Americans with high cholesterol levels } \\
\text { take dietary steps to bring it down. }\end{array}$ \\
\hline \multicolumn{3}{|r|}{1988} \\
\hline$-W$ & $5 / 12$ & A saturated fat passes one test on cholesterol. \\
\hline$+\mathrm{M}$ & $6 / 21$ & $\begin{array}{l}\text { Bad blood: A kind of cholesterol shows a special link to coronary disease: called } \mathrm{Lp}(\mathrm{a}) \text {, it also offers } \\
\text { tantalizing hint of how arteries may get clogged; is this the smoking gun?. }\end{array}$ \\
\hline$+\mathrm{M}$ & $11 / 17$ & Low levels of "good" cholesterol may pose heart risk, some studies say. \\
\hline$+\mathrm{W}$ & $12 / 6$ & Cholesterol drive to raise cholesterol awareness, sales. \\
\hline \multicolumn{3}{|r|}{1989} \\
\hline$+\mathrm{W}$ & $6 / 6$ & Researchers suggest how heart attacks come from ignored type of cholesterol. \\
\hline$+\mathrm{M}$ & $7 / 7$ & A high level of cholesterol is found in more Americans. \\
\hline$+\mathrm{S}$ & $11 / 15$ & $\begin{array}{l}\text { Cholesterol's link to heart disease called undeniable; American Heart Association and National Heart, } \\
\text { Lung, and Blood Institute report. }\end{array}$ \\
\hline$+\mathrm{M}$ & $11 / 15$ & Studies show diet, drugs can reverse arterial clogging. \\
\hline$-\mathrm{W}$ & $11 / 28$ & Some cholesterol tests are inaccurate, U.S. aide says; Department of Health and Human Services. \\
\hline \multicolumn{3}{|r|}{1990} \\
\hline$-\mathrm{W}$ & $1 / 18$ & Negative oat bran study may crimp marketing efforts. \\
\hline$+\mathrm{S}$ & $2 / 8$ & Scientists isolate cholesterol "receptor", adding piece to heart disease puzzle; MIT study. \\
\hline$+\mathrm{W}$ & $2 / 8$ & $\begin{array}{l}\text { Univ. oat bran study raised further questions; Syracuse University study paid for by Quaker Oats } \\
\text { Company claims lower cholesterol levels. }\end{array}$ \\
\hline$-\mathrm{W}$ & $3 / 2$ & Portable machines that test cholesterol at malls make large errors, studies say. \\
\hline$+\mathrm{M}$ & $3 / 23$ & Modest change in diet can slow clogging of arteries, study finds; USC study from JAMA. \\
\hline$+\mathrm{W}$ & $4 / 3$ & Psyllium's ability to cut cholesterol backed by studies; Kellogg Company funded. \\
\hline$-\mathrm{W}$ & $4 / 13$ & $\begin{array}{l}\text { All in the genes; new medical strategy against heart disease probes inherited flaws; scientists begin to } \\
\text { see why cholesterol accumulates in blood of some people. }\end{array}$ \\
\hline$+\mathrm{W}$ & $5 / 11$ & A perilous journey; how to shop for groceries healthfully without fouling up the heart. \\
\hline$+\mathrm{S}$ & $6 / 14$ & $\begin{array}{l}\text { Men curbing cholesterol level can cut risk of cardiac death, study indicates; New England Journal of } \\
\text { Medicine. }\end{array}$ \\
\hline
\end{tabular}

¡Summaries as described in The Wall Street Journal Index and National Newspaper Index.

$\$(+)$ and $(-)$ indicate whether an article supports or weakens the link between red meat consumption and coronary disease; W, $\mathrm{M}$, and $\mathrm{S}$ indicate weak, moderate, or strong articles as described in the text. 


\section{Appendix Table 2. Components of the Commodity Research Bureau Futures} Price Index

\begin{tabular}{lll}
\hline \multicolumn{1}{c}{1983} & \multicolumn{1}{c}{$1984-86$} & $1987-90$ \\
27 contracts & 27 contracts & 21 contracts \\
\hline barley & barley & cattle (live) \\
broilers & cattle (live) & cocoa \\
cattle (live) & cocoa & coffee \\
cocoa & coffee & copper \\
coffee & copper & corn \\
copper & corn & cotton \\
corn & cotton & crude oil \\
cotton & crude oil & gold (N.Y.) \\
eggs & flaxseed & heating oil (\#2) \\
flaxseed & gold (N.Y.) & hogs \\
grease wool & heating oil (\#2) & oats (Chi.) \\
hogs & hogs & lumber \\
oats (Chi.) & oats (Chi.) & orange juice \\
orange juice & lumber & platinum \\
platinum & orange juice & pork bellies \\
plywood & platinum & silver (N.Y.) \\
pork bellies & pork bellies & soybeans \\
potatoes & potatoes & soybean meal \\
rapeseed & rapeseed & soybean oil \\
rye & rye & sugar “11" \\
silver (N.Y.) & silver (N.Y.) & wheat (Chi.) \\
soybeans & soybeans & \\
soybean meal & soybean meal & \\
soybean oil & soybean oil & \\
sugar "11" & sugar "11" & \\
wheat (Chi.) & wheat (Chi.) & \\
wheat (Mpls.) & wheat (Mpls.) & \\
\hline
\end{tabular}


http://www.jstor.org

\title{
LINKED CITATIONS
}

- Page 1 of 2 -

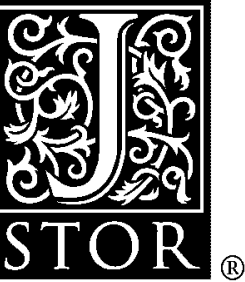

You have printed the following article:

Health Risk and the Demand for Red Meat: Evidence from Futures Markets

Rodney G. Robenstein; Walter N. Thurman

Review of Agricultural Economics, Vol. 18, No. 4. (Oct., 1996), pp. 629-641.

Stable URL:

http://links.jstor.org/sici?sici=1058-7195\%28199610\%2918\%3A4\%3C629\%3AHRATDF\%3E2.0.CO\%3B2-7

This article references the following linked citations. If you are trying to access articles from an off-campus location, you may be required to first logon via your library web site to access JSTOR. Please visit your library's website or contact a librarian to learn about options for remote access to JSTOR.

\section{References}

\section{Cholesterol Information and Shell Egg Consumption}

Deborah J. Brown; Lee F. Schrader

American Journal of Agricultural Economics, Vol. 72, No. 3. (Aug., 1990), pp. 548-555.

Stable URL:

http://links.jstor.org/sici?sici=0002-9092\%28199008\%2972\%3A3\%3C548\%3ACIASEC\%3E2.0.CO\%3B2-F

\section{Structural Change in the Demand for Meat}

Jean-Paul Chavas

American Journal of Agricultural Economics, Vol. 65, No. 1. (Feb., 1983), pp. 148-153.

Stable URL:

http://links.jstor.org/sici?sici=0002-9092\%28198302\%2965\%3A1\%3C148\%3ASCITDF\%3E2.0.CO\%3B2-E

\section{Testing for Structural Change: The Demand for Meat}

Seungmook Choi; Kim Sosin

American Journal of Agricultural Economics, Vol. 72, No. 1. (Feb., 1990), pp. 227-236.

Stable URL:

http://links.jstor.org/sici?sici=0002-9092\%28199002\%2972\%3A1\%3C227\%3ATFSCTD\%3E2.0.CO\%3B2-C

\author{
Modeling the Pattern of Structural Change in U.S. Meat Demand \\ Giancarlo Moschini; Karl D. Meilke \\ American Journal of Agricultural Economics, Vol. 71, No. 2. (May, 1989), pp. 253-261. \\ Stable URL: \\ http://links.jstor.org/sici?sici=0002-9092\%28198905\%2971\%3A2\%3C253\%3AMTPOSC\%3E2.0.CO\%3B2-J
}


http://www.jstor.org

\section{LINKED CITATIONS \\ - Page 2 of 2 -}

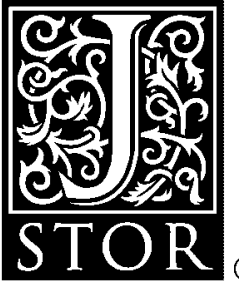

The Poultry Market: Demand Stability and Industry Structure

Walter N. Thurman

American Journal of Agricultural Economics, Vol. 69, No. 1. (Feb., 1987), pp. 30-37.

Stable URL:

http://links.jstor.org/sici?sici=0002-9092\%28198702\%2969\%3A1\%3C30\%3ATPMDSA\%3E2.0.CO\%3B2-L 